\title{
イギリスの農村計画 一計画から管理への動き-
}

\author{
小山 善 彦*
}

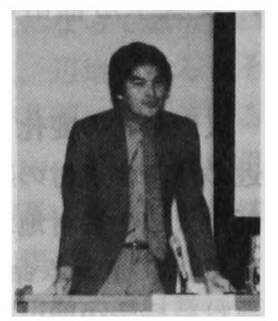

\section{I はじめに}

イギリスは高度に都市化が進んだ国である。そ れは，人口や経済活動の都市集中といったレベル を一早く脱し，今では都市人口の農村流入による 新しい社会形態の形成といったレベルに達しつつ ある。しかしその一方で，イギリスは農業国でも ある。国土の $3 / 4$ を農地が占め, 国民食糧の $2 / 3$ を賄っている。しかし, 農業の近代化が大きく進 展した現在, 広大な農地を管理する人口は全就業

人口の $3 \%$ に満たない。

イギリスの国土は平担で, 我が国の感覚でいえ ば丘陸地という程度である。承知のように, イギ リスでは17世紀から18世紀にかけて囲い込みが行 われ，農地の統合が全国的規模で一気に進んだ。 これは, 現代的意味での圃場整備であり，したが ってイギリスでは戋場整備への取り組みは, 農村 整備の主要課題となっていない。

本報告ではこうしたイギリスの実情を踏まえ， 高度に都市化が進んだ社会，そこにおける都市と 農村の関係, 農村計画の課題, 理念, 手法などに 焦点をあててみたい。

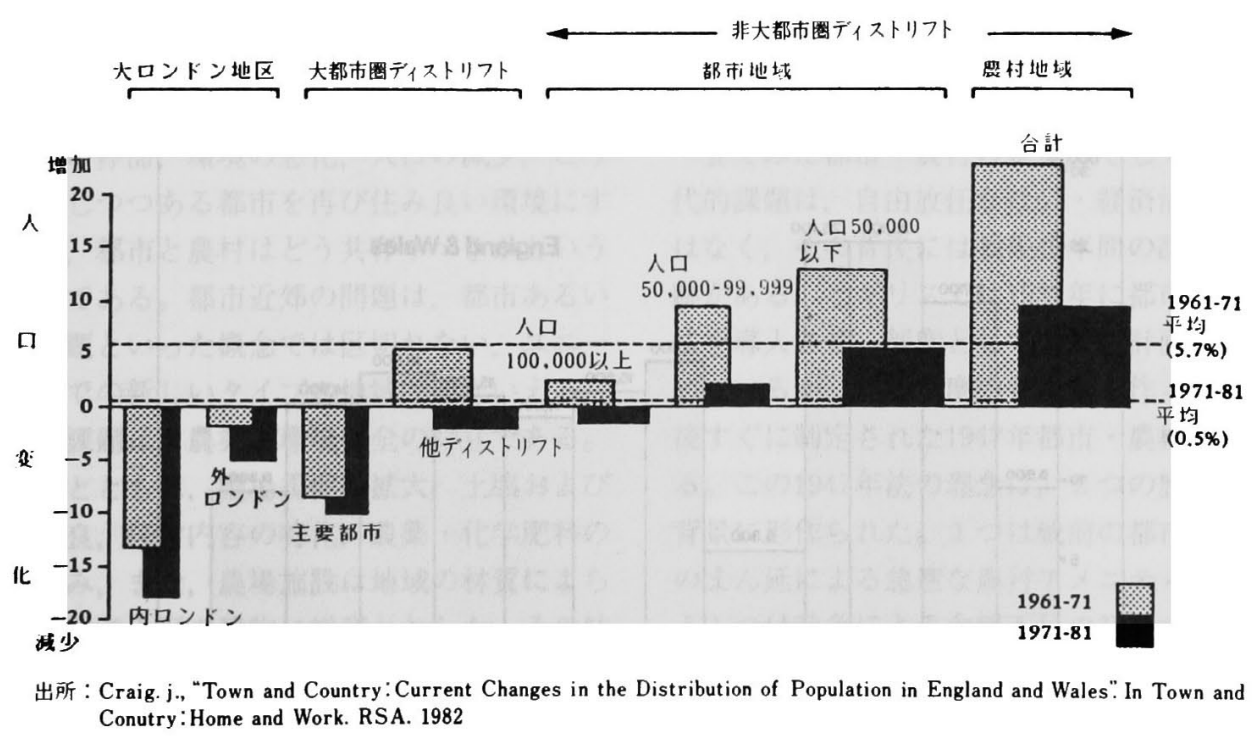

図 1 都市人口規模別にみた人口移動：イングランドとウェールズ(1961-71と1971-81)

\footnotetext{
* 農村生活総合研究センター
} 


\section{II．変貌する都市と農村}

\section{1 人口分布の変化}

最近の都市と農村の新しい関係を象徵する動き は, 都市人口の農村地域への逆流現象である。イ ギリスでは，産業革命による重工業都市の形成 と, 農村地域での囲い込みにより，18１9世紀に かけて人口の急激な都市集中が進んだ。都市人口 の占める割合は1851年にはすでに 5 割を超え，19 世紀はじめにはほほ定常状態に達した。しかし, 都市への人口の流れは次第に停滞から逆流に転 じ，とくに1960年代になると，悪化した都市環境 から逃れて郊外, さらに農村での居住を求める動 きが顕著となった。図 1 は過去20年間の人口の流 れを都市の人口规模別にみたものであるが，大都 市からの転出と, より農村的な地域への転入が顕 著に表われている。

\section{2 土地利用粠造の变化}

1981年のイギリスの土地利用は，全国土 2,400 万 ha のうち, 農地が76. $1 \%$ (耕地 $29 \%$, 草地 21.2 $\%$ ，粗放牧地 $25.9 \%)$ ，林地が9.1\%，都市地域が $8.5 \%$ ，その他 $6.3 \%$ となっている。最近では, 粗
放牧地の減少と林地の拡大が特徽的である。粗放 牧地の転用の 6 割は植林で, 残りは耕地や草地一 の改良である。この粗放牧地の転用は, 野生生物 の生息地あるいは自然的景観の隇少につながり， 農林業開発と桭境保全の間で激しい論争を生む背 景となっている。農地の都市的利用への転用は, 都市スプロールが顕著にみられた1920～30年代に 大きく進んだが，戦後になって開発規制が施行さ れ，また最近では経済不況も重なって，転用面皘 は次第に減少してきている。それでも，年間約 10,000haの転用がある（図 2）。

\section{3 農業構造の变化}

戦後，イギリスの農業は飛躍的な発展を遂げた が, その過程で農業構造も大きく変わった。農場 数 (イングランド) は1947-79年の30年間に約半 分に減少し，その一方で，200ha以上を経営する 農場が徐々に增加した。農場数の変化とともに, 農地の自作地化も進んだ。全農地に占める借地農 地の割合（イングランドとウェールズ）は, 1891 年の $85.7 \%$ から 1974 年の $46.4 \%$ に下がり,一方, 自 作あるいは主に自作という農場数の割合は, 1914 年の $11 \%$ から 1969 年の $61 \%$ へと增加した。さら に, 農業従事者数, とりわけ労働者数の減少も著 しく，1944年に 90 万あった労㗢人口は，1977年に

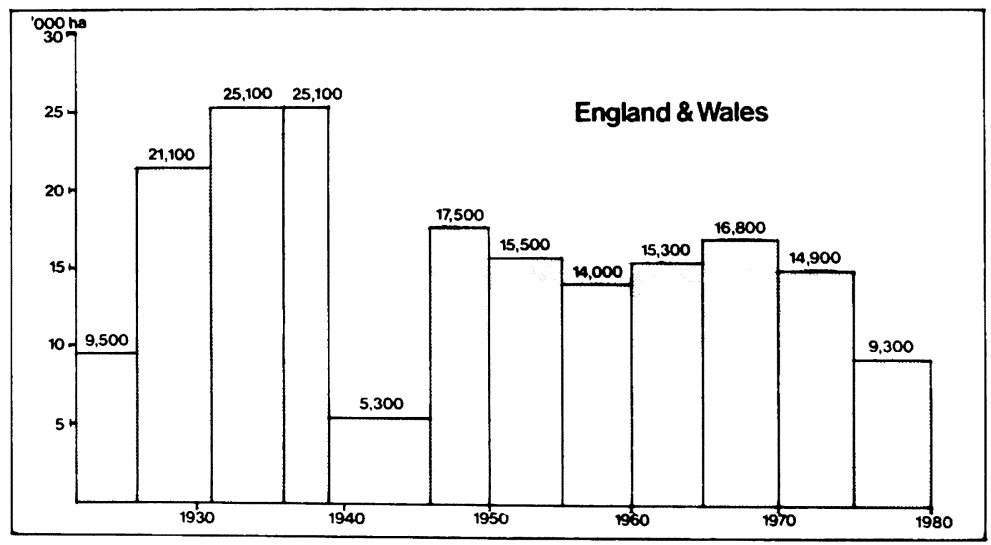

出所 : Best. R. and Anderson. M., Land-use Structure and Change in Britain, 1971 to 1981. The Planner, Vol. 70 No 11,1984

図 2 農地の都市的利用への転用(イングランドとウェールズ) 
は37万となった。中でも常雇，それも男性の減少 が目立ち，その分パートタイム，あるいは季節・ 臨時雇用の比重が増している。こうして全就業人 ロに占める農林水産業関係の割合は，1980年には $2.0 \%$ にまで下がった。

\section{III. 農村計画の現代的課題}

このように，社会経済的な意味での都市と農村 の区切りがますます不明確になり，また，農村地 域での主要産業としての農業の構造およびその国 民経済的な位置づけが大きく変わるにつれ，農村 地域はその地域的条件によってさまざまな課題を 抱えるようになっている。それらは次の 3 つに大 別される。

まず第 1 に，都市近郊農村における地域管理の 問題である。都市近郊農村は住宅や施設利用, 都 市住民のための野外レクリエーションなどへの需 要が大きく，そのため土地利用と景観秩序の混乱 が進行している。都市近郊に多い優良農地も, 都 市住民による加害行為があるために効率的な経営 ができなかったり，ひどい場合には耕作放棄され る耕地もでてきている。こうした問題は大都市近 郊でとくに著しく，そこでは都市再開発（インナ ーシティ）問題ともつながっている。すなわち, 経済活動の停滞, 環境の悪化, 人口の減少, こう して衰退しつつある都市を再び住み良い環境にす るために，都市と農村はどう共存すべきかという 問題意識である。都市近郊の問題は, 都市あるい は農村問題といった概念では区切れない, ユニー クな環境での新しいタイプの地域問題といえる。

第 2 の課題は，農業と環境保全の対立である。 農業発展とともに，戒場規模の拡大，土壤および 品種の改良, 経営内容の特化, 農薬・化学肥料の 多投が進み，また，農場施設は地域の材質によら ない近代的で大型の建物に様変わりした。その結 果, 伝統的農業景観を形作ってきた戋場生垣が徹 去され，作目の単一化も進んで景観が単調とな り，また田園風景にそぐわない建物も入り込んで きた。加えて, 野生生物生息地の破壊や, 化学薬 品の多投による水質および土壤の污染も進んだ。
第 3 の課題は，遠隔地にある集落の社会問題で ある。産業革命以来, 農村地域からの人口流出は 一貫して続いてきた。最近になって都市人口の逆 流がみられているとはいえ，辺地になるとその影 響も受けず，人口の流出が基調になっているとこ ろが多い，転入者があるといっても，定年退職者 や週末利用者などの場合が多いため, 年齢構造の 高齢化が進み，また地域に根づいた活力がなかな か生まれてこない。農業雇用数の絶対数の減少と いう伝統的なプッシュ要因に加え, 最近ではさら に，都市住民の転入による住宅価格の高騰によ り，地元住民が家を買えずに地方都市に転出する という事態もみられている。

現在の農村地域の課題は, 国民生活の社会, 経 済, 政治的変化，それらの農村地域への影響を背 景として生まれてきた。農業を含めた産業および 交通面での技術革新，国民所得の上昇，教育水準 の向上, 労働時間の減少，そしてこれらによって 促された価值観の変化, 人口の移動, 政府介入の 増大など。主に農村地域外で発生したこれらの変 化を, 農村地域が受け入れ, 吸収した結果が, 現 代の課題となって現われている。

\section{IV. 農村計画の理念と計画制度}

II でみた都市・農村の変化，そして IIIでみた現 代的課題は, 自由放任な社会・経済活動の結果で はなく，その背後には戦後40年間の計画実践の足 跡がある。イギリスでは1932年に都市・農村計画 法を導入させ, 制度としての農村計画の歩みを始 めているが, 現行制度の骨組みを作ったのは, 戦 後すぐに制定された1947年都市・農村計画法であ る。この1947年法の理念は，2つの歴史的経験を 背景に形作られた。1つは戦前の都市スプロール のまん延による急速な農村アメニティの破壊, も う1つは戦争による食糧不足の経験である。

これらの経験を計画制度に反映させるための作 業をしたのが，戦時中の1941年に設立されたスコ ット委員会である。同委員会は, 農業の振興, 農 村アメニティの保全, 農村地域社会の活性化, の 必要性を強調し，とくに，「農業が健全であれば 
図3イギリスにおける計画課題と制度の変遷

\begin{tabular}{|c|c|c|c|c|}
\hline 年代 & 計 画 課 題 & 土地利用 - 杗落政策 & $\begin{array}{l}\text { 景観保全・レクレー } \\
\text { シ } \quad \text { ン 政 策 }\end{array}$ & 自然保誶政策 \\
\hline 1900 & 都市環境の改善 & 1909都市住宅等計画法 & \multirow{4}{*}{$\begin{array}{c}\text { (1931山村地域 } \\
\text { アクセス法) }\end{array}$} & \\
\hline & & （1919計画法） & & \\
\hline & $\begin{array}{l}\text { 都市スプロールの防止 } \\
\text { 景観アメニティの保全 }\end{array}$ & 1932都市・農村計画法 & & \\
\hline 1940 & $\begin{array}{l}\text { 農業振舆 } \\
\text { 農村集落の蘇生 }\end{array}$ & (1942スコット報告書) & & \\
\hline 1950 & & 1947都市・農村計画法 & $\begin{array}{l}1949 \text { 国立公園・田園地 } \\
\text { 域アクセス法 }\end{array}$ & \\
\hline 1960 & ○野外レクレーションの振興 & 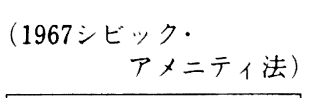 & & \\
\hline & & 1968都市 · 農村計画法 & 1968田園地域法 & \\
\hline 1970 & ○野生生物・生態采の保全 & （1971都市·農村計画法） & & \\
\hline 1980 & & $\begin{array}{l}\text { (1980地方政府 } \cdot \\
\text { 土地 } \cdot \text { 計画法) }\end{array}$ & & $\begin{array}{l}\text { 1981野生生物 · } \\
\text { 田園地域法 }\end{array}$ \\
\hline
\end{tabular}

地域社会も健全となり，環境も保全される」という 考え方に立ち，農業振興をその中心課題とすべきこ とを提言した(Scott Report, Cmnd 6378,1942)。 戦後の農村計画の枠組みは, このスコット報告書 の内容を噶矢とし, その整備が図られてきたわけ であるが、ここでは現行の関連法のうちから， (1)土地利用・集落, (2)景観保全・レクリエーショ

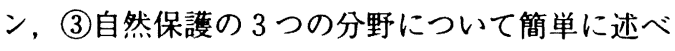
る(図 3 )。

\section{1 都市・農村計画法}

まず，都市および農村を含めた地域計画の法 的基盤を与えたのが, 1947年都市・農村計画法 （1968年，1971年に改正）である。都市・農村計 画は、「開発計画」と「開発规制」という $2 つ の$ 手法をもって，主に土地利用の規制を取り扱う。

「開発計画」の策定では, カウンティ (県) がま ずカウンティ全体の開発構想を示すストラクチャ 一・プランを作り，これに準拠した形で，基本的 にはディストリクト（市町村）がローカル・プラ ンを作成する。ローカルプランは図 4 に示すよう

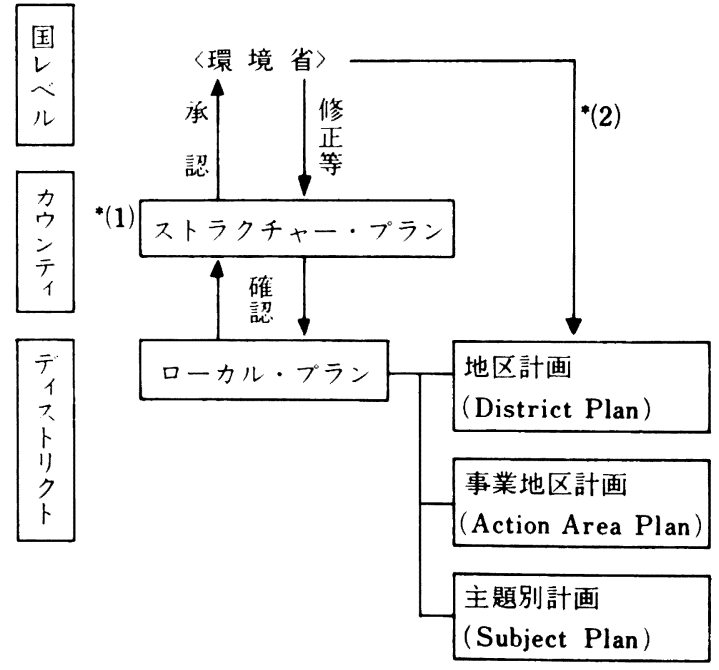

注：(1)ローカルプランは多くはディストリフトが作成するが、カウン ティが行う場合もある。

(2)ローカルプランは地方自治体が独自に承認でき、㜊境省を通さ なくてもよい。たたし、懪境省は「コール・イン」によって干 涉できるようになっている。

図4イギリスの開発計画体制 
に 3 種類あり，地域の実状に合わせて異なる夕イ プの計画ができるようになっている。ストラクチ ヤー・プラン, ローカルプランともに, 開発の規 制・誘導に主眼が置かれており，積極的な事業の ための計画という性格は薄い。農業政策は自治体 の管轄ではないため, 土地利用の枠組み設定以外 は，農業についての言及は少ない。また集落政策 も,この開発計画の中で取り扱われる。

この開発計画の内容を担保する目的で行われる のが開発規制で, 開発者の申請を自治体が個別審 査する形で, 開発の誘導を図っている。「開発」 の定義が極めて包括的で，ほとんどすべての行為 が規制の対象となるが，農林業に関係する行為は その対象から外されている。

\section{2 田園地域法}

田園地域法は，農村地域の景観保全とレクリエ ーション振興を目的とする法律である。その前身 の1949年国立公園・田園地域アクセス法を拡大 · 改組する形で，1968年に制定された。農村全域を 対象とし，同法第11項には，農村地域に関係する すべての機関は「農村地域における自然美および アメニティの保護に配慮すること」という義務規 定が設けられている。この点を監視し，またレク リエーション振興を図るために, 田園地域委員会 が設置されている。この田園地域委員会を通し て, 景観保全やレクレーション事業のための助成 金が，事業主体の公私および団体・個人を問わず 広く交付されている。

\section{3 野生生物・田園地域法}

1981年野生生物・田園地域法は，農業と自然保 護との対立を背景に，その調和を図る目的で制定 された。これによって，国立公園のような特定地 域内の農地に限り, 地方自治体は農場主との間に 経営内容についての協定が結べることになった。 この「任意協定 従来から紳士協定として採用されてきたものでと くに目新しいものではなく，そのことを含めた法 律自体の実効性を疑問視する声も多い。しかしい ずれにしても，自由放任を原則としてきた農業 に対し，その活動内容の制限が検討され，不十分
とはいえ法律の制定にまで至ったことは，将来の 農村計画を考える上で大きな意味をもっている。 以上まとめると, 現在の農村地域の課題は複雑 に錯綜しており，問題の性格も，単なる土地利用 という物理的な問題だけでなく, 関係者間の利害 調整といった社会問題としての性格をも带びるよ うになっている。既存の制度体系は，個々の法律 が別個の目的の遂行のためにあり，相互に衝突こ そすれ，互いの利害を調整する機能は持っていな い。その機能を果たすべき都市・農村計画制度 は, 一応開発計画によって地域の総合的計画を行 う体制を導入させてはいるが，その主要な関心は いぜん物的な器の整備，それも開発の規制にあ り，利害の調整を図るといった積極的側面にそし w。

\section{V．新しいアプローチの模索}

さて，このような計画課題および制度的背景の なかで, 最近問題解決のための新しいアプローチ がいくつか試みられるようになっている。その内 容は, アーバン・フリンジ, 農業と環境, 地域社 会それぞれの課題領域によってさまざまであり， 活動を進めている主体もまたいろいろである。こ こではそのうちの一つ, アーバン・フリンジの問 題解決のために開始されたグランドワーク事業に ついて紹介しておきたい。

\section{1 田園地域委員会の実験}

グランドワーク事業は, 前述した田園地域委員 会の活動成果を背景に，1980年の初めに開始され た。田園地域委員会は1968年の発足以来，とくに 農村地域の「管理 (management) を主要テーマ として取り上げ，その手法開発のために実験事業 を手掛けてきた。そのやり方は，まず特定の地域 を選定し，そこの地域管理を主にプロジェクト・ オフィサー 1 人に担当させる方式である。オフィ サーは地域住民と協力しながら地域にある農村問 題を発掘し, 同時に問題解決のための可能性を探 る。そして解決のための処方せん（マネージメン ト・プラン) を描き，それを実行に移すわけであ 
るが, その際, 自治体や地元企業, ボランティア 団体, 学校, 農業者といった地域の団体や個人に 働きかけ，その協力を得ながら作業をすすめると ころに特色がある。

\section{2 グランドワークの試み}

グランドワークは,このオフィサー方式をさら に一歩進めたものである。アプローチの仕方はオ フィサー方式と同じであるが，グランドワークで は地域活動の核として，チャリティ団体であり， 専門家集団でもあるトラスト が置かれて いる。この事業の第 1 の特徵は,「問題を解決す る」ことが最優先されている点にある。法定計画 にありがちな長期的目標の設定や価値論争はやら ず，住民の眼を通して問題をみつめ, 地域の参加 によってその速やかな解決を図ることに徹してい る。もう一つの特徵は,「パートナーシップ」の 考え方にある。いろいろな問題の中に各利害者間 の共通利益を見いだし，関係者によるパートナー シップ (協力関係) によって問題解決に取り組ん でいる。図 5 にあるように，トラストを中心に， 農家, 私企業, 自治体や学校, ボランティア団体 などと横のつながりがつくられ，これに対して全 国，広域レベルの公的機関が援助を与えている。 グランドワークは, 新しい地縁的枠組み, 補助金 方式, 活動体制による地域問題への対処手法とい える。

\section{VI.さいごに}

都市化が国土のすみずみまで浸透し，農業従事 者の割合が $3 \%$ を切ったイギリスでは，農村地域 の計画は広く全国民的な課題であり，関心事であ る。したがって, 農業の振興や農村地域社会の活 性化などに加え, アメニティ保全, レクリエーシ ョン振興, 自然保護なども農村計画の中心的な課 題になっている。そして歴史的に振り返れば, 農 村計画の課題は次第に膨み，多様化してきた。し かし現在，これらの多様化した課題をうまく調整

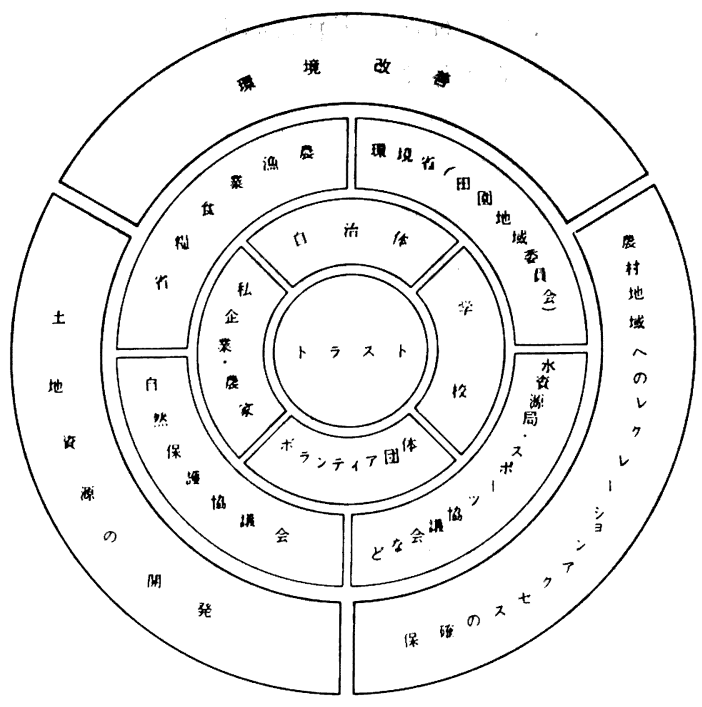

出所：農村開発企画委貝会、「英国の譬村整備(2)-80年代の新しい波」 農村工学研究37、1985

困 5 グランドワークのパートナーシップ

する手法が確立されているとは言い難い。

戦後のイギリス農村計画は，国民的合意を背景 にかなり理想追求型の計画として出発した。計画 の目指すべきゴールは明らかであり，計画者の役 割もはっきりしていた。しかし，現在は模索の時 代である。計画目標の合意が崩れ，どの活動を優 先し, どういう農村地域をつくればいいのか。開 発規制に偏った法定計画手法の限界がいわれる中 で,どういう体制・手法がもっとも効果的に機能 しうるのか。価值観多様化社会における計画の機 能は何か, また, 計画者が果たすべき役割は何な のか。これらは, 最近の文献のほとんどが取り上 げるテーマである。

最近イギリスでみられる新しい試みは,こうし た文脈の中に位置づけられよう。そして，これら の試みにおいて，「管理 」アプローチ がキーワードになっていることは注目に値する。 「管理」の中味についてはいま一つ吟味を要する が,この「計画から管理へ」という表現の中に, 新しい農村計画のあり方を模索するイギリスの動 きが感じられる。 


\section{British Rual Planning: Movement from Planning to Management by Yoshihiko Oyama (The Rural Life Research Institute)}

In Britain, where urbanization has penetrated deep into the countryside and where the agricultural work force has become less than $3 \%$ of the total, how to plan and manage rural areas is of deep concern to the whole nation. This article follows the chronological change in rural planning issues and how statutory planning has responded. With this background, current issues in highly urbanized countryside are examined by focusing on three areas: environmental deterioration and land use conflict in the urban fringe, conflict between modern farming and conservation, and the deprivation of remoter rural communities. It has become increasingly clear that the traditional statutory 'planning' approach cannot cope with them properly, and the author looks into the underlying reasons. This is followed by reference to a new 'management' approach and its practical outcome, known as 'Groundwork', which introduces an idea of partnership with the charitable and professional Groundwork Trust acting as a new change agent. It is regarded as an unconventional approach initiated in the contemporary conditions and possibilities.

\section{Village Renewal in the F.R. of Germany: \\ A Co-operation of Urban Construction and Rural Land Consolidation \\ by Ren Azuma (Japanese National Research Institute of Agriculural Economics)}

This paper focuses its attention on the historical development and status quo of the legal framework of village renewal in the F.R. of Germany.

The village renewal in the F.R. of Germany contrasts with that in Japan, in that the former includes the development or renewal of built-up areas and the removal or large-scale improvement of houses.

This village renewal has been conducted as part of rural land consolidation projects since the early 19 th century. After World War I especially in Preussen, it was put into common practice due to the development of large-scale and intensive cattle farming which demanded modernization of facilities. After World War II urbanization and growing demand for urban land uses in rural areas made it more popular.

Two legal bases are necessary for implementing the village renewal projects; the first one makes it possible to establish a plan to control land-use and housing, and the other gives the authority power to reoder land and realize the plan. The two bases are delivered by the Bundesbaugesetz (Urban Construction Act) on the urban planning side and the Flurbereinigungsgesetz (Land Consolidation Act) on the rural planning side. In this way the two planning sides share the task and co-operate with each other legally. Actually in many cases the rural land consolidation authority carries out the task, because the combination with rural land consolidation gives many advantages and subsidiary programs are available only on the rural planning side.

It is not self-evident that the rural land consolidation projects can include the built-up area of a village and implement village renewal measures. Historically we can trace back the efforts on the rural planning side to firm its legal base for village renewal. 